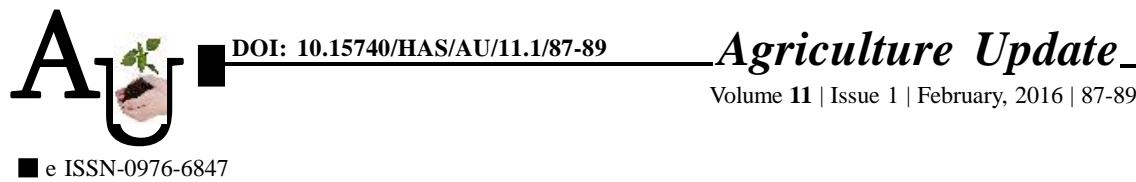

Visit us : www.researchjournal.co.in

\title{
Research Note: Constraints faced by beneficiaries in proper utilization of the assistance received under Prime Minister Rozgar Yojana
}

\section{Article Chronicle: \\ Received : \\ 29.11.2014; \\ Accepted : \\ 27.01.2016}

\section{B.C. BOCHALYA AND R.M. JAVIA}

SUMMARY : PMRY is a scheme launched by GOI in 1993 for the educated unemployment youths. The success of any programme remains with the proper utilization of assistance provided for the objectives. The study reveals that "inadequate supply of assistance" was major constraints followed by "disbursal of assistance" is delayed to beneficiaries. So, it is suggested that to overcome from these constraints there should be better co-ordination between official and beneficiaries.

How to cite this article : Bochalya, B.C. and Javia, R.M. (2016). Constraints faced by beneficiaries in proper utilization of the assistance received under Prime Minister Rozgar Yojana. Agric. Update, 11(1): 87-89.

KEY WoRDS:

PMRY,

Constraints

\section{R.M. JAVIA}

Krishi Vigyan Kendra (JAU) Nana-kandhasar (Chotila)

SURENDRANAGAR (GUJARAT) INDIA

See end of the article for authors' affiliations 